九州大学学術情報リポジトリ

Kyushu University Institutional Repository

\title{
Variation of Chromosome Number in Plants and Regenerated Plantlets of Bupleurum falcatum L.
}

Shon, Tae-Kwon

Laboratory of Crop Science, Faculty of Agriculture, Kyushu University

Haryanto, Totok Agung Dwi

Laboratory of Crop Science, Faculty of Agriculture, Kyushu University

Can, Nguyen Duy

Laboratory of Crop Science, Faculty of Agriculture, Kyushu University

Yoshida, Tomohiko

Laboratory of Crop Science, Faculty of Agriculture, Kyushu University

https://doi.org/10.5109/24189

出版情報: 九州大学大学院農学研究院紀要. 42 (1/2)，pp.39-42，1997-12. Kyushu University バージョン：

権利関係 : 
J. Fac. Agr., Kyushu Univ., $42(1 \cdot 2), 39-42$ (1997)

\title{
Variation of Chromosome Number in Plants and Regenerated Plantlets of Bupleurum falcatum $\mathrm{L}$.
}

\author{
Tae-Kwon Shon, Totok Agung Dwi Haryanto, Nguyen Duy Can \\ and Tomohiko Yoshida
}

Laboratory of Crop Science, Faculty of Agriculture, Kyushu University, Fukuoka 812-81, Japan

(Recived July 24, 1997 and accepted August 25,1997)

\begin{abstract}
Variation of chromosome number in plants and regenerated plantlets of $B$. falcatum was studied using three cultivars, originated from Kumamoto and Fukuoka, Japan and Jeongseon, Korea. Within and among cultivars, there was a variablity in chromosome number. The basic chromosome number from plants was shown as $2 n=26,2 n=26$ and $2 n=20$ for the cultivar from Kumamoto, Jeongseon, and Fukuoka, respectively. Various kinds of aneuploidy were observed from the plants as $2 n=18,22,23,24,25,48$. Chromosome number of regenerated plantlets by anther culture was $2 n=13$, which was originared from a $2 n=26$ plant.
\end{abstract}

\section{INTRODUCTION}

B. falcatum has variation of chromosome number in different geographical origins as well as in the same cultivar with $2 n=20,26,32$ of three basic types (Amano et al., 1989; Chung et al., 1995; Ohta et al., 1986; Ohta, 1991). Furthermore, variation of chromosome number was observed in the regenerated plants from tissue culture (Amano et al., 1989; Kohda et al., 1990). Therefore, it is necessary to observe chromosome numbers for roots from seeds of various cultivars and for plantlets regenerated through anther culture to confirm the haploidy.

The objective of this study is to obtain more information on the chromosome number variation for different cultivars and regenerated plantlets through anther culture.

\section{MARERIALS AND METHODS}

Three cultivars, originated from Jeongseon, Korea and Fukuoka and Kumamoto, Japan, were used for somatic chromosome observation. Seeds were germinated for 1 month in a jiffy pot at $20^{\circ} \mathrm{C}$ and the root tips were used for chromosome observation. Root tips were pretreated with a solution of $0.1 \%$ colchicine for 2 hours at $20^{\circ} \mathrm{C}$. After fixation in ethanol/acetic acid (3:1\%) for $30 \mathrm{~min}$. at $5^{\circ} \mathrm{C}$ and macerated with $1 \mathrm{~N} \mathrm{HCl}$ for 5 -7 min. at $60^{\circ} \mathrm{C}$, they were stained in an $1 \%$ aceto-orcein solution.

For chromosome observation of regenerated plantlets, root tips, obtained from regenerated plantlets through anther culture, were treated with $2 \mathrm{M}$ 8-hydrooxyquinline for $4-5$ hours at $20^{\circ} \mathrm{C}$, fixed in $45 \%$ glacial acetic acid for 5 to $10 \mathrm{~min}$. at $5{ }^{\circ} \mathrm{C}$, macerated with a mixture solution of $1 \mathrm{~N} \mathrm{HCl}$ and $45 \%$ glacial acetic acid (2:1) for 10 seconds at $60^{\circ} \mathrm{C}$ and stained with $1 \%$ aceto-orcein. 


\section{RESULTS}

In $B$. falcatum, the chromosome formed dark stained chromatin threads and spread over the nucleus uniformly at interphase (Fig. 1, A). At prophase, all chromosomes were concentrated homogeneously along with their long axis, thus early and late concentrated segments were not distinguishable (Fig. 1, B and C). At metaphase, all chromosomes were observed very clearly (Fig. 2).

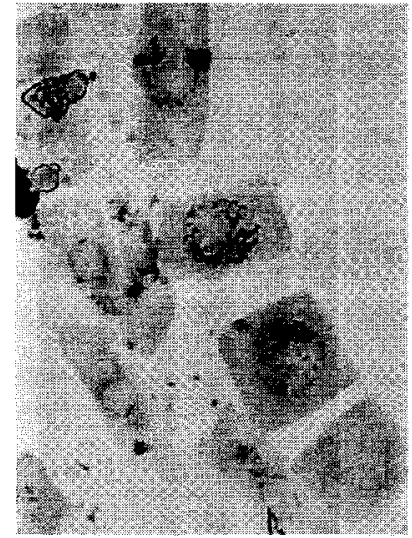

Interphase(A)

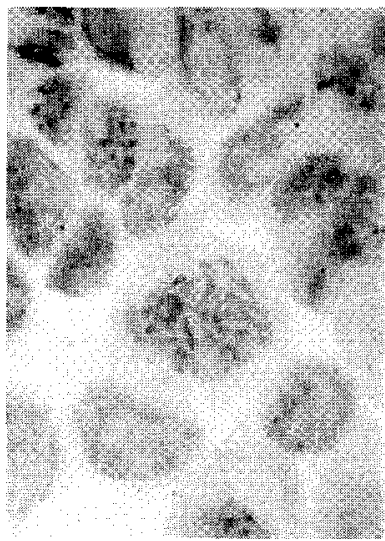

Early prophase (B)

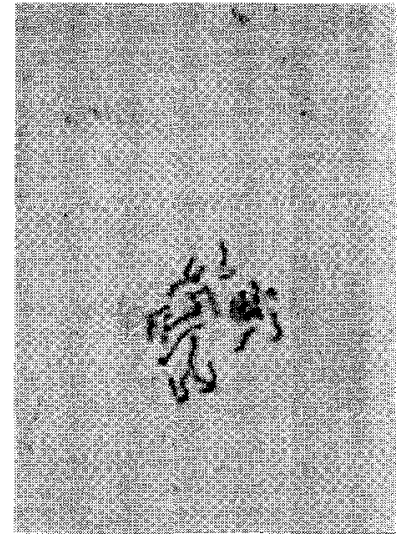

Late prophase(C)

Fig. 1. Somatic chromosomes at interphase and prophase in B. falcatum

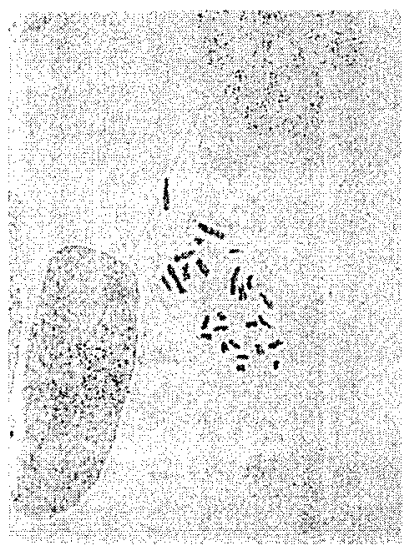

Jeongseon $(2 n=26)$

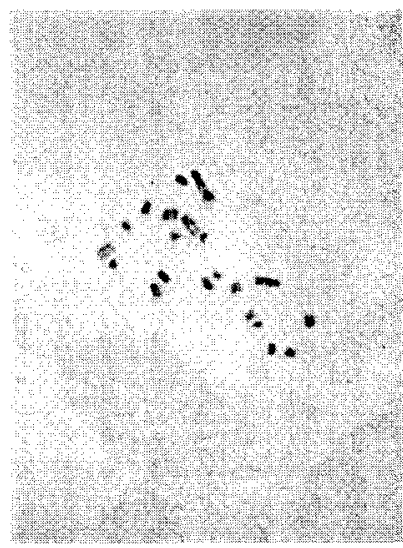

Fukuoka (2n=20)

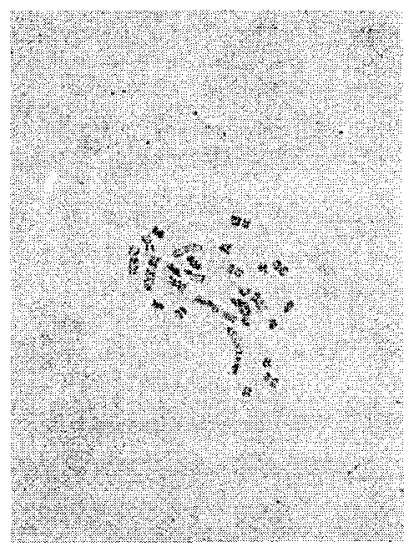

Kumamoto $(2 \mathrm{n}=26)$

Fig. 2. Somatic chromosomes of B. falcatum of three cultivars from Jeongseon, Fukuoka and Kumamoto. 

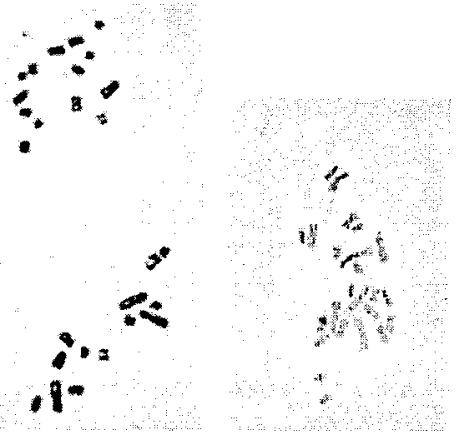

Jeongseon $(2 \mathrm{n}=25,23)$

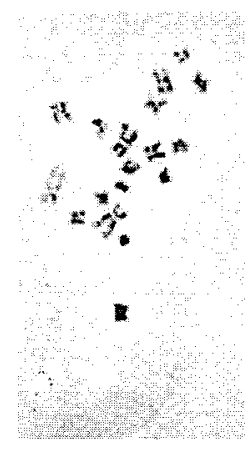

Fukuoka $(2 n=18)$

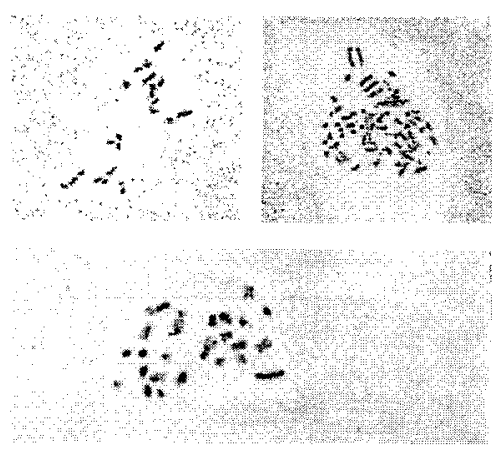

Kumamoto $(2 \mathrm{n}=48,24,22)$

Fig. 3. Variation of somatic chromosomes of $B$. falcatum from seeds of three cultivars from Jeongseon, Fukuoka and Kumamoto.

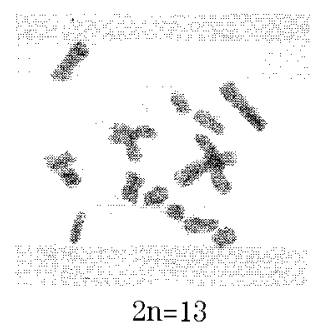

Fig. 4. Chromosome in a root tip cell of a regenerated plantlet.

Fig. 2 shows somatic chromosomes of three different cultivars. Chromosome number was determined to be $2 n=20$ (the cultivar from Fukuoka), and $2 n=26$ (the cultivars from Kumamoto and Jeongseon).

Variation of somatic chromosomes from seeds within a cultivar is represented in Fig. 3. Aneuploids of somatic chromosome were found as follows; $2 n=23,25$ for the cultivar from Jeongseon, $2 n=18$ for that from Fukuoka, and $2 n=22,24,48$ for that from Kumamoto (Fig. 3 and Table 1). Fig. 4 shows that the haploid plantlets originated from anther culture of $B$. falcatum had a half of the diploid chromosome number $(n=13)$ of their originated plant $(2 \mathrm{n}=26)$.

\section{DISCUSSION}

In this study, somatic chromosome numbers of $2 n=20,26$ (the cultivars from Fukuoka and Kumamoto) were observed. This number confirms previous reports of Ohta et al. (1986) and Ohta (1991). The chromosome number of the cultivar from Jeongseon was determined for the first time as $2 n=26$. Most of the chromosome numbers was the same 
Table 1. Chromosome numbers of the plants from seeds regenerated plantlets by anther culture of $B$. falcatum.

\begin{tabular}{|c|c|c|c|c|}
\hline \multirow{2}{*}{$\begin{array}{l}\text { Cultivars } \\
\text { from }\end{array}$} & \multicolumn{2}{|c|}{ Plants from seeds } & \multicolumn{2}{|c|}{ Plantlets from anther culture } \\
\hline & $\begin{array}{c}\text { Chromosome } \\
\text { number }\end{array}$ & $\begin{array}{c}\text { Number of } \\
\text { plants observed }\end{array}$ & $\begin{array}{c}\text { Chromosome } \\
\text { number }\end{array}$ & $\begin{array}{l}\text { Number of } \\
\text { plantlets }\end{array}$ \\
\hline \multirow[t]{4}{*}{ Kumamoto } & 48 & 1 & 13 & observed \\
\hline & 26 & 22 & & \\
\hline & 24 & 1 & & \\
\hline & 22 & 1 & & \\
\hline \multirow[t]{3}{*}{ Jeongseon } & 26 & 17 & 13 & 4 \\
\hline & 25 & 1 & & \\
\hline & 23 & 1 & & \\
\hline \multirow[t]{2}{*}{ Fukuoka } & 20 & 6 & & \\
\hline & 18 & 1 & & \\
\hline
\end{tabular}

as the basic type with a few variation in this study. Ohta (1991) reported that $B$. falcatum showed polymorphic variation in external morphology such as plant size, shapes of stem and basal leaves, size of florets, and had various chromosome numbers, i.e. $2 \mathrm{n}=19,20,21,22-23,24,25,27,27-28,27-29,29-31,30,30-31,32-34,33,34,37,40$.

In regenerated plants by tissue culture, the variation in chromosome number differed among different cultivars; large frequency of chromosome number variation for the cultivars from Hiraodai (93.9\%) and that from Kirishima (94.1\%) and no variation for that from Mishima (Amano et al., 1989). Kohda et al. (1990) reported that propagations of the shoot primordia of $B$. falcatum were highly stable in the chromosome number as less than $1 \%$ in frequency of chromosome number variation. In the present study, all regenerated plantlets by anther culture were stable in chromosome number as $n=13$, though a few materials were counted for regenerated plantlets.

B. falcatum is a cross pollinating species and genetically heterozygous and was found to have a lot of intraspecific variation in external morphology as well as internal cytology. Thus, for classification and identification of cultivars and production of high yield and quality cultivars, homozygous plants through tissues culture are needed.

\section{REFERENCES}

Amano, A., K. Fujimoto, H. Ohashi, K. Matsunaga and H. Mizukami 1989 Chromosome number variation in Bupleurum falcatum plants regenerated through somatic embryogenesis of callus cultures. Shoyakugaku Zasshi, 43: 13-18

Amano, A., K. Fujimoto and H. Ohashi 1989 Geographical variation in somatic chromosome numbers of Bupleurum falcatum L.. Shoyakugaku Zasshi, 43: 192-194

Chung, S. H., J. W. Bang and H. W. Choi 1995 Cytogenetic analysis of Bupleurum falcatum L. cultivated in Korea. Korean J. Medicinal Crop Sci., 3: 61-65

Kohda, H., A. Namera, Y. Hamamoto and T. Okamoto 1990 Propagation of Bupleurum falcatum by shoot tip culture. Shoyakugaku Zasshi, 44: $38-41$

Ohta S. 1991 Cytogenetical study on the speciation of Bupleurum falcatum L. (Umbelliferae). J. Sci. Hiroshima Univ, Ser. B, Div. 2., 23: 273-348

Ohta, S., H. Mitsuhashi and R. Tanaka 1986 Aneuploidal variation in Bupleurum falcatum L. from Japan. J. Jap. Bot., 61: 212-216 